\title{
A Decade of Ecosystem-Scale Research at an Aridland Constructed Treatment Wetland
}

\author{
Daniel L. Childers* \\ School of Sustainability, Arizona State University, Tempe, AZ, United States
}

\section{OPEN ACCESS}

Edited by: José Francisco Gonçalves Júnior, University of Brasilia, Brazil

Reviewed by: John R. White, Louisiana State University, United States Alex Valach, University of California, Berkeley, United States

${ }^{*}$ Correspondence:

Daniel L. Childers dan.childers@asu.edu

Specialty section: This article was submitted to

Freshwater Science,

a section of the journal

Frontiers in Environmental Science

Received: 02 July 2020

Accepted: 23 September 2020

Published: 16 October 2020

Citation:

Childers DL (2020) A Decade of Ecosystem-Scale Research at an Aridland Constructed Treatment

Wetland.

Front. Environ. Sci. 8:576936. doi: 10.3389/fenvs.2020.576936
Cities are increasingly pursuing more resilient and sustainable futures. One way to do so is by the increased use of Urban Ecological Infrastructure (UEI), including constructed treatment wetlands (CTW). This strategy is particularly important for aridland cities with scarce water resources. In this paper I synthesize nearly 10 years of systemslevel research at the Tres Rios CTW in Phoenix, AZ, United States. Since July 2011, a research team that includes dozens of student volunteers has been sampling for herbaceous biomass and productivity, water quality, transpiration rates, and aquatic metabolism. We also quantify belowground biomass and plant tissue nutrient content annually, and measured greenhouse gas fluxes from 2012 to 2014. Our peak summer biomass values are among the highest reported in the literature, and high rates of transpiration are associated with this biomass. Using our whole-system water budgets and tracer studies we have documented a slow movement of surface water into the marsh from adjacent open water areas that is driven by transpirational losses and that we refer to as the "biological tide." With our nitrogen $(\mathrm{N})$ budgets for the whole system and the vegetated marsh we showed that roughly $50 \%$ of the annual $\mathrm{N}$ uptake by the vegetated marsh is driven by new water entering via this biological tide. Our aquatic metabolism sampling suggested that the $\mathrm{N}$ uptake associated with the autotrophic water column was roughly $27 \%$ of the average annual $\mathrm{N}$ uptake by the vegetated marsh. The marsh is a source of $\mathrm{CH}_{4}$ and $\mathrm{N}_{2} \mathrm{O}$ across the air-water interface and the plants are a net source of $\mathrm{CH}_{4}$ but a net sink for $\mathrm{N}_{2} \mathrm{O}$. Our combined flux estimates suggest that the Tres Rios marshes are a net sink for greenhouse gas equivalents because of this plant-mediated net uptake of $\mathrm{N}_{2} \mathrm{O}$. Finally, over the years our Tres Rios CTW project has provided a platform for dozens of students and young people to experience ecological research, both in the field and in the lab.

Keywords: constructed treatment wetlands, urban ecological infrastructure, nitrogen budgets, water budgets, transpiration, wastewater treatment, biological tide, aridland cities

\section{INTRODUCTION}

The global human population is becoming increasingly urban, with over $50 \%$ of all people currently living in cities (Wigginton et al., 2016) and increasing to a likely $80 \%$ by 2050 (Grimm et al., 2008). Over the last century, cities have transformed into "sanitary cities" that rely on highly centralized, engineered, and expensive infrastructure to keep inhabitants healthy (Melosi, 2000; Grove, 2009). These "gray" infrastructure strategies are largely able to meet short-term demands 
(Ahern, 2011, 2013), but they often impose large systemic inertias that hinder a city's ability to pursue novel, adaptive, or transformative solutions (Childers et al., 2014). Engineered gray infrastructure approaches are premised on adaptive rigidity (Gilrein et al., 2019; Helmrich and Chester, 2020) and "fail-safe" approaches (Chester and Allenby, 2019) that are becoming an increasing liability in the face of an uncertain future in both climate and human demographics.

In an effort to adapt to this future uncertainty, many cities are increasingly using "design with nature" solutions, and engaging the "design-ecology nexus" (Childers et al., 2015). In doing so, many cities are turning to Urban Ecological Infrastructure (sensu Childers et al., 2019) for more sustainable and resilient solutions. Urban Ecological Infrastructure (UEI) is all infrastructure in a city that supports ecological structure and function and thus provides ecosystem services to urban residents. This broad, all-encompassing concept for nature in cities includes obvious forms, such as parks, residential yards, community gardens, lakes and rivers, and street trees. But it also includes less obvious forms of nature in cities, including vacant lots, agricultural fields, canals, even flower pots with blooming plants. Childers et al. (2019) categorized UEI into terrestrial, aquatic, and wetland ecosystem types because each type supports unique ecological structures and functions and thus provides unique ecosystem services. My focus here is on wetland UEI; specifically on a type of wetland UEI that is being increasingly used to adaptively manage urban water resources: Constructed Treatment Wetlands.

Constructed treatment wetlands (CTW) are a relatively low cost and low maintenance solution to urban wastewater and water reclamation challenges (Greenway, 2005; Wallace and Knight, 2006; Kadlec and Wallace, 2009; Nivala et al., 2013). The most common type of CTW is surface-flow treatment wetlands designed to remove pollutants from wastewater effluent or stormwater (Kadlec and Wallace, 2009; Fonder and Headley, 2013). These wetlands typically include a mix of open water areas, emergent vegetation, and waterlogged soils (Fonder and Headley, 2013), with designs that are tailored to local or regional characteristics including water quality regulations and climate (Fonder and Headley, 2010; Tanner et al., 2012). Cities in arid and semi-arid climates have a particular interest in using wetland UEI, particularly CTW, to better manage limiting water resources as many of these cities are using water reclamation strategies to meet current and future water demands (Greenway, 2005).

My objective here is to synthesize and summarize ecosystemscale research that we have conducted for nearly a decade at a large CTW in Phoenix, AZ, United States. Phoenix is an aridland city where virtually all municipal effluent is reused in some way (Metson et al., 2012) and the CTW we have been studying is an example of the adaptive use of UEI to facilitate urban water reuse. The challenge and trade-off of using CTW in arid or semi-arid climates is balancing potentially large water losses to the atmosphere in cities where water reuse is important (Green et al., 2006). The research findings I summarize here have been carried out by the Wetland Ecosystems Ecology Lab at Arizona State University (WEEL) ${ }^{1}$. Since July 2011, dozens of student

${ }^{1}$ http://weel.asu.edu volunteers and a few paid staff have been involved with this intensive effort. Some of those students conducted their honors theses or graduate research projects at this CTW. I highlight the contributions of these colleagues in the acknowledgments section of this paper.

\section{MATERIALS AND METHODS}

The ecosystem-scale research that the WEEL has been conducting since July 2011 at the Tres Rios CTW, which is part of the largest wastewater treatment plant in Phoenix, includes quantifying an array of structural and functional ecological variables. The following sampling has been, and continues to be, completed every other month. This includes quantifying: (1) the live biomass and productivity of the emergent herbaceous vegetation; (2) whole-system nutrient and water budgets; and (3) open water aquatic metabolism. We quantify other variables, such as plant tissue nutrient content and belowground plant biomass dynamics, on an annual schedule. Lastly, greenhouse gas flux dynamics were quantified as part of a Ph.D. dissertation research effort (Ramos, 2017). In all cases, details of the methods have already been published, but I summarize our field and lab approaches below for clarity.

\section{Site Description}

The research that I synthesize here has been conducted at the Tres Rios CTW. Construction was completed in early 2010, and our research began in July 2011. We focus on the largest wetland treatment cell that has 21 ha of vegetated marsh and 21 ha of open water with several small islands (Figure 1). We differentiate between two systems: the entire 42 ha system and the 21 ha vegetated marsh subsystem. Tres Rios receives 95,000-270,000 $\mathrm{m}^{3} \mathrm{~d}^{-1}$ of effluent, depending on the time of year, and the system has a designed water residence time of 4 days. Open water depths are 1.5-2.0 m, while vegetated marsh depths average $25 \mathrm{~cm}$; these values are temporally consistent because of management practices. The wetlands were originally planted with seven native species of wetland plants: Typha latifolia, Typha domingensis, Schoenoplectus acutus, Schoenoplectus americanus, Schoenoplectus californicus, Schoenoplectus maritimus, and Schoenoplectus tabernaemontani (Weller et al., 2016).

The climate of Phoenix, Central Arizona, and the Sonoran Desert is characteristically hot and dry. Long-term average monthly temperatures range from $18.9^{\circ} \mathrm{C}$ in December to $41^{\circ} \mathrm{C}$ in July, but temperatures as high as $46^{\circ} \mathrm{C}$ are common in the summer. Relative humidity in the summer, before the monsoon season begins, can be as low as $2 \%$. Average annual rainfall is $20 \mathrm{~cm}$, with large interannual variability. Roughly half of this rainfall comes during the summer monsoon season and the other half during winter frontal passages.

\section{Herbaceous Plant Biomass and Primary Production (Every Other Month)}

Primary production is an important ecosystem variable because plants convert solar energy into organic energy that then fuels 


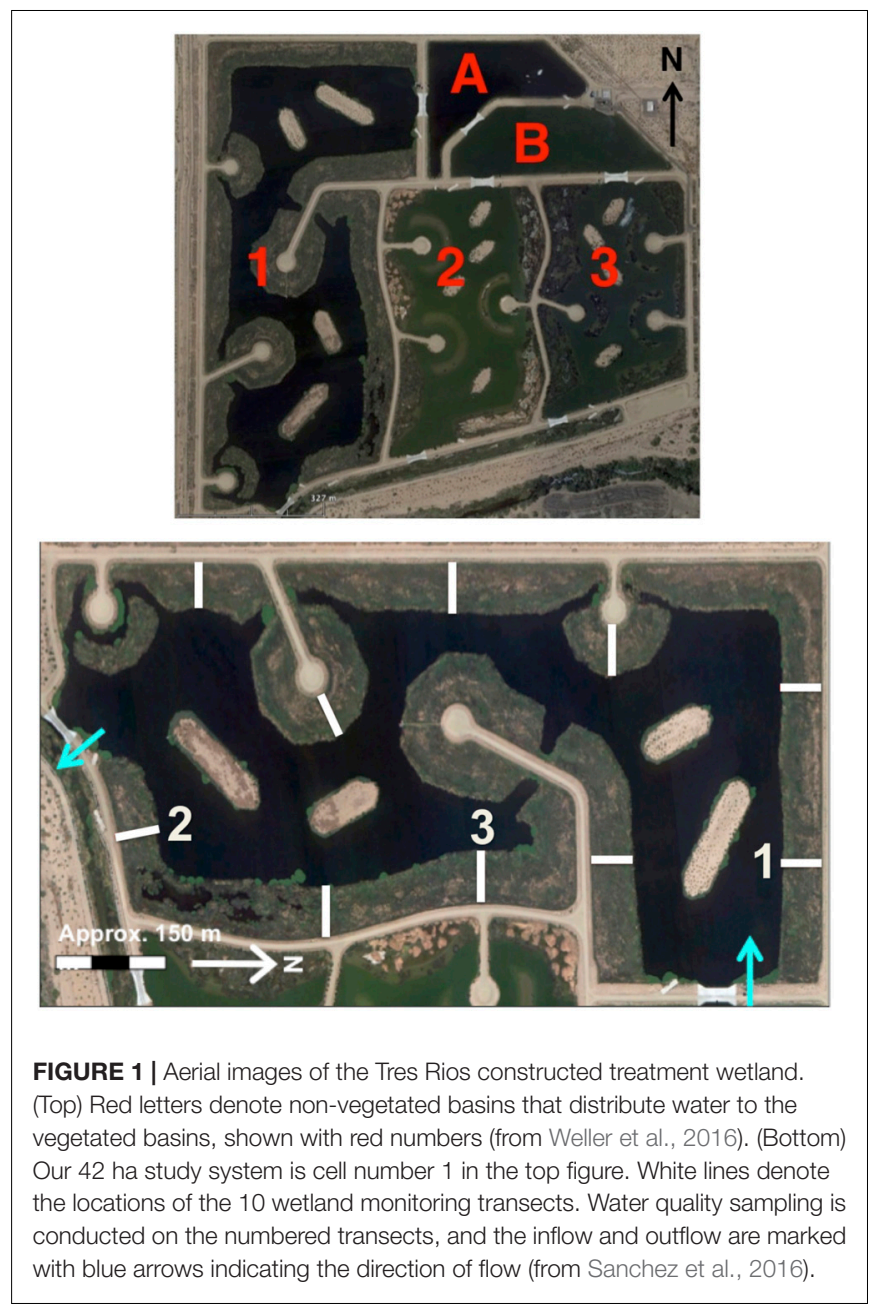

trophic dynamics and the rest of the ecosystem. We have quantified aboveground live biomass every other month along 10 marsh transects (shown in Figure 1) by applying species-specific phenometric models to measurements of plants made in the field (Weller et al., 2016). These measurements are made on all plants that fall within $0.25 \mathrm{~m}^{2}$ quadrats that are randomly located along the 10 marsh transects, with 5 quadrats per transect. Our phenometric models are able to explain $>85 \%$ of the variation in live biomass for all plant species in the marsh (see Weller et al., 2016 for methodological details).

\section{Belowground Plant Biomass and Plant Nutrient Budgets (Annual)}

Wetland plants obtain the water and nutrients they need from the soil, so quantifying belowground biomass and tissue nutrient content are important components of our marsh $\mathrm{N}$ budget. We collect and analyze belowground biomass samples annually using a $0.018 \mathrm{~m}^{2}$ PVC corer to a soil depth of $20-30 \mathrm{~cm}$. Triplicate cores are extracted from monospecific stands of all plant species present in the marsh after first harvesting all aboveground biomass from within the core. Root cores are carefully cleaned in sieves and dead plant material is removed. These samples, plus all aboveground samples, are dried, weighed, and analyzed for tissue nutrient content (see Crane, 2019 for methodological details).

\section{Plant Transpiration, Open Water Evaporation, and the Whole-System Water Budget (Daily)}

We quantify water losses via plant transpiration every other month using a LICOR LI-6400 (LI-COR, Lincoln, Nebraska, United States) handheld infrared gas analyzer. Leaf-specific water vapor flux is measured on all plant species in the marsh and the infrared gas analyzer captures local atmospheric variables that are critical drivers of transpiration, including photosynthetically active radiation, air temperature, and relative humidity (Sanchez et al., 2016). We scale these leaf-specific transpiration rates in space, or into whole-system transpiration volumes, using our bimonthly estimates of species-specific live macrophyte biomass [per section "Herbaceous Plant Biomass and Primary Production (Every Other Month)" above]. We use hourly meteorological data from an on-site meteorological station to scale these leaf-specific transpiration rates in time, resulting in hourly estimates of whole system transpirational losses. These same hourly meteorological data are used to estimate open water evaporation. We calculate the whole system water budget as (inflow + precipitation) (outflow + transpirational loss + open water evaporation; see Sanchez et al., 2016 for methodological details).

\section{Whole System Water Budget and the "Biological Tide" (Daily)}

During the hot, dry summer months large amounts of water are lost from the vegetated marsh via transpiration-as much as 20$25 \%$ each day-and we have documented a horizontal advection of surface water into the marsh from adjacent open water areas to replace this loss (Bois et al., 2017). We have named this phenomenon the "Biological Tide" (Sanchez et al., 2016), because it resembles horizontal water movement in coastal wetlands in response to astronomical tides. To our knowledge, this is the first time that control of surface hydrology by wetland plants has ever been reported. Our whole system water budget includes this input of new water to the vegetated marsh, and our nutrient budget accounts for new nutrients and pollutants being delivered to the marsh via the biological tide (Treese et al., 2020).

\section{Water Quality and Nutrient Budgets (Daily and Every Other Month)}

In Arizona, CTW are designed and managed to remove nitrogen $(\mathrm{N})$, which is the limiting nutrient in Arizona surface waters (Grimm and Fisher, 1986) and is thus the main macronutrient regulated by law. For this reason, $\mathrm{N}$ has been the focus of our long-term research at Tres Rios. Our research follows a dualgradient experimental design: The first gradient is the entire 42 ha system from inflow to outflow (blue arrows in Figure 1) and the second gradient is specific to the 21 ha vegetated marsh, with 10 evenly distributed transects (white lines in Figure 1). Every other month we collect triplicate surface-water grab samples at the inflow and outflow and at the open water interface and shore ends of three of the marsh transects (numbers shown in Figure 1; 
Sanchez et al., 2016; Treese et al., 2020). We analyze these samples for inorganic $\mathrm{N}$ content (nitrite $=\mathrm{NO}_{2}{ }^{-}$, nitrate $=\mathrm{NO}_{3}{ }^{-}$, and ammonium $=\mathrm{NH}_{4}{ }^{+}$). We measure oxygen concentrations, $\mathrm{pH}$, and conductivity as well.

To calculate $\mathrm{N}$ flux at the whole-system scale we multiply $\mathrm{N}$ concentrations at the inflow and outflow by their respective water fluxes, which are monitored by the City of Phoenix Water Services Department. We calculate N fluxes at the marsh scale in two ways. First, we estimate the average water volume overlying the marsh, accounting for underwater plant stem volume. This water volume is multiplied by the concentration difference between the open water and shore samples collected along our three marsh transects. Next we account for additional $\mathrm{N}$ being supplied by the biological tide-these water volumes are dynamically estimated. This new water volume is also multiplied by the open water and shore sample $\mathrm{N}$ concentration difference. The simple sum of the two is the total $\mathrm{N}$ being removed by the marsh either daily or monthly daily (see Treese et al., 2020 for methodological details).

\section{Open Water Aquatic Metabolism (Every Other Month)}

Half of the 42 ha Tres Rios CTW is open water, and the water residence time in the system is short enough (4 days) that it is likely much of the effluent entering the system never encounters vegetated marsh. Thus, it is helpful for us to have a firstorder estimate of how $\mathrm{N}$ is turning over in the water column in response to aquatic primary productivity and heterotrophic respiration. We use the simple light-dark bottle oxygen flux technique to document these processes. Triplicate light and dark $300 \mathrm{ml}$ BOD bottles are incubated, with water from the inflow and outflow, for several hours. The difference between initial and final oxygen concentrations approximates aquatic net primary productivity (NPP, light bottles) and ecosystem respiration (ER, dark bottles). We use Secchi Disk depths to determine the photic zone and a basic light extinction curve to integrate NPP with depth. We integrate ER with depth below the photic zone and use the same measurements to estimate nighttime heterotrophy. These estimates are scaled in space by volumetric conversion to the 21 ha of open water in the system, and we use the Redfield ratio to estimate the balance of $\mathrm{N}$ uptake (via NPP) and remineralization (via ER; See Evans, 2020 for methodological details).

\section{Greenhouse Gas Fluxes (Every Other Month, 2012-2014)}

Wetlands are highly productive ecosystems that are typically significant sinks for atmospheric carbon. However, wetlands are also known sources of other greenhouse gases, in particular methane $\left(\mathrm{CH}_{4}\right)$ and nitrous oxide $\left(\mathrm{N}_{2} \mathrm{O}\right)$. Between March 2012 and January 2014 we quantified water-air fluxes of these two greenhouse gases within the Tres Rios marsh every other month. The transects labeled 1 and 2 in Figure 1 were sampled, at three locations along each transect: Near the shore, near the marsh-open water interface, and between the two. We deployed triplicate floating chambers at each location and sampled headspace gas for $45 \mathrm{~min}$ three times in a day. Headspace gas samples were analyzed for $\mathrm{CH}_{4}, \mathrm{~N}_{2} \mathrm{O}$, and carbon dioxide $\left(\mathrm{CO}_{2}\right.$; see Ramos, 2017 for methodological details).

Our transpiration measurements identified large amounts of water vapor loss from the emergent plants, particularly during the hot, dry summer months (Sanchez et al., 2016). Because of this we inferred that the plants may also be substantial conduits for the efflux of greenhouse gases. We used clear acrylic chambers $(7 \mathrm{~cm} \times 20 \mathrm{~cm}, 0.76 \mathrm{~L})$ fitted over individual Typha sp. leavesthe dominant species group-at two locations in the canopy to quantify gas flux from the plants. The chambers had $1 \times 2 \mathrm{~cm}$ openings in the top and bottom for the leaf, and were sealed with adhesive putty to make the chambers gas tight. Gas samples were extracted from the chambers every $15 \mathrm{~min}$ for $45 \mathrm{~min}$. We conducted sampling twice in the winter (2014) and three times in the summer (2015) along the same transects and locations as the air-water flux work. The leaf tissue within the chambers was harvested, dried, and weighed for biomass and the gas samples were analyzed for $\mathrm{CH}_{4}, \mathrm{~N}_{2} \mathrm{O}$, and $\mathrm{CO}_{2}$ (see Ramos, 2017 for methodological details).

\section{RESULTS}

\section{Herbaceous Plant Biomass and Primary Production}

Our sampling of aboveground live plant biomass, begun in July 2011, shows regular seasonal trends of maximum biomass in July (Figure 2). The two species of Typha and Schoenoplectus acutus + Schoenoplectus tabernaemontani are grouped together because the phenometric models for the individual species were not significantly different (Weller et al., 2016). The maximum of $600 \mathrm{MT}$ for the 21 ha marsh (Figure 2) equates to a maximum of $2,860 \mathrm{gdw} \mathrm{m}^{-2}$. The plant community was relatively diverse when the system was new, in 2011 and 2012, but by 2014 Schoenoplectus americanus and Schoenoplectus maritimus had been effectively extirpated from the marsh (Figure 2).

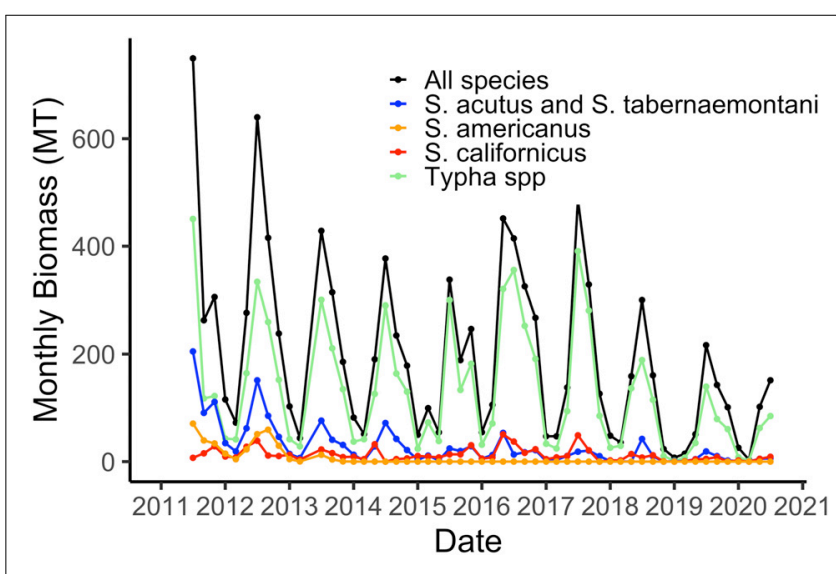

FIGURE 2 | Total aboveground live plant biomass in the 21 ha marsh system for all species combined and for the four species groups defined by the phenometric models (Weller et al., 2016). 
TABLE 1 | Aboveground (AG) and belowground (BG) N content of each plant species group normalized to the total contribution of each species group to total biomass (modified from Weller et al., 2016; Crane, 2019).

\begin{tabular}{|c|c|c|c|c|c|c|}
\hline Year & SAC/STAB AG $\left(\mathrm{g} \mathrm{m}^{-2}\right)$ & SAC/STAB BG $\left(\mathrm{g} \mathrm{m}^{-2}\right)$ & SCAL AG $\left(g^{-2}\right)$ & SCAL BG $\left(\mathrm{g} \mathrm{m}^{-2}\right)$ & TYP AG $\left(\mathrm{g} \mathrm{m}^{-2}\right)$ & TYP BG $\left(\mathrm{g} \mathrm{m}^{-2}\right)$ \\
\hline 2011 & $14.8 \pm 1.8$ & $3.5 \pm 0.01$ & $0.5 \pm 0.1$ & $6.2 \pm 0.1$ & $33.8 \pm 4.6$ & $38.2 \pm 0.2$ \\
\hline 2012 & $11 \pm 1.3$ & $6.7 \pm 0.01$ & $3 \pm 0.6$ & $4.6 \pm 0.02$ & $25.1 \pm 3.4$ & $42 \pm 0.01$ \\
\hline 2013 & $5.5 \pm 0.7$ & $10.3 \pm 0.02$ & $1.8 \pm 0.4$ & $6.5 \pm 0.03$ & $22.5 \pm 3.1$ & $77.1 \pm 0.1$ \\
\hline 2014 & $5.2 \pm 0.6$ & No data & No data & No data & $21.8 \pm 3$ & No data \\
\hline 2015 & $1.8 \pm 0.2$ & $14.3 \pm 0.1$ & $1.1 \pm 0.2$ & $11.1 \pm 0.01$ & $22.6 \pm 3.1$ & $135 \pm 0.1$ \\
\hline 2016 & $1 \pm 0.1$ & $3.5 \pm 0.01$ & $2.9 \pm 0.6$ & $4.9 \pm 0.01$ & $26.7 \pm 3.6$ & $88.7 \pm 0.1$ \\
\hline 2017 & $1.3 \pm 0.2$ & $7.3 \pm 0.01$ & $3.8 \pm 0.8$ & $1.5 \pm 0.01$ & $29.2 \pm 4$ & $67.8 \pm 0.1$ \\
\hline 2018 & $3.1 \pm 0.4$ & No data & $0.6 \pm 0.1$ & No data & $14.2 \pm 1.9$ & No data \\
\hline
\end{tabular}

SAC/STAB, Schoenoplectus acutus and tabernaemontani; SCAL, Schoenoplectus californicus; TYP, Typha domingensis and latifolia.

These relatively low-stature species were apparently outcompeted for light by the other five taller and more robust species. Additionally, we have observed a gradual domination of the plant community by the two species of Typha, although all five remaining species remain part of the marsh plant community (Figure 2).

\section{Belowground Plant Biomass and Plant Nutrient Budgets}

The $\mathrm{N}$ content of the plants in the vegetated marsh is an important component of the marsh $\mathrm{N}$ budget. We measure belowground biomass and the $\mathrm{N}$ content of aboveground and belowground tissues for all species groups annually. The contributions of each to the average aerial $\mathrm{N}$ budget are scaled by the live biomass of each species group, and because Typha sp. dominate the plant community this species group also dominates the plant N budget (Table 1; Weller et al., 2016; Crane, 2019). When scaled to the entire 21 ha marsh, aboveground plant biomass accounted for 3.7-10.3 MT N (17.6-49.0 $\left.\mathrm{gN} \mathrm{m}^{-2}\right)$ and belowground biomass for 11.2-33.7 MT N (53.3-160.0 $\left.\mathrm{gN} \mathrm{m}^{-2}\right)$. These aboveground values are on par with the 5-10 MT N (23.8$47.6 \mathrm{gN} \mathrm{m}^{-2}$ ) that the marsh takes up annually (section "Water Quality and Nutrient Budgets," below), suggesting that annual plant productivity is an important control on $\mathrm{N}$ flux into the marsh and that the belowground biomass $\mathrm{N}$ pool contributes significantly to this $\mathrm{N}$ uptake.

\section{Plant Transpiration, Open Water Evaporation, and the Whole-System Water Budget}

Using hourly data from the on-site meteorological station we are able to estimate water losses via plant transpiration on a daily basis (Figure 3). As with biomass, transpiration rates are highest in the hot, dry summer months when temperatures routinely reach $45^{\circ} \mathrm{C}$ and relative humidity is often $5 \%$ or lower. The maximum of $12,000 \mathrm{~m}^{3} \mathrm{~d}^{-1}$ in water lost via the plants from the 21 ha marsh equates to a maximum of $0.056 \mathrm{~m}^{3}$ $\mathrm{m}^{-2}$, or a daily loss of nearly $6 \mathrm{~cm}$ from the surface of the marsh (Figure 3). However, as I note in section "Whole System Water Budget and the "Biological Tide" below, more typical summer transpiration rates are considerably lower than this maximum. These large daily losses of water via transpiration drive the "Biological Tide," which we describe in more detail in section "Whole System Water Budget and the "Biological Tide" below (Bois et al., 2017). Notably, these large transpirational losses are also drawing oxygenated, N-rich water into the soils and likely enhancing coupled nitrification-denitrification (sensu Martin et al., 2003). Interestingly, even though Typha has always dominated the plant community in biomass (Figure 2), the three Schoenoplectus species play a disproportionately large role in transpirational water losses (Figure 3).

\section{Whole System Water Budget and the "Biological Tide"}

Our whole system water budget accounts for inputs via the effluent inflow point (Figure 1) and precipitation, which is relatively rare in Phoenix with a long-term average annual rainfall of $20 \mathrm{~cm}$. Outputs from the system include the effluent outflow plus daily water losses via transpiration and open water evaporation, both estimated per Sanchez et al. (2016). The City of Phoenix Water Services department provides us with daily inflow and outflow data, and outflow rates are consistently lower than inflow rates by $5-10 \%$ in the winter and $25-30 \%$ in the summer. On average, transpiration + evaporation was

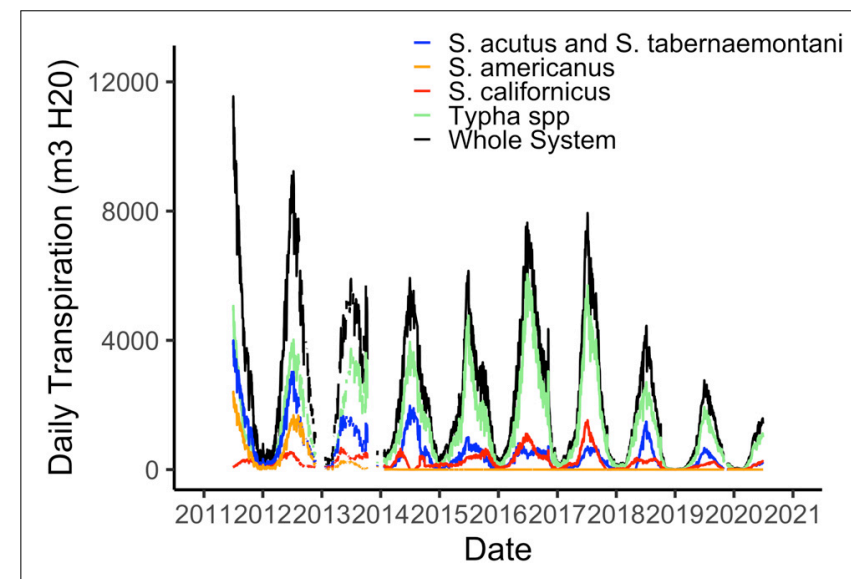

FIGURE 3 | Total daily water losses via plant transpiration from the 21 ha marsh system for all species combined and for the four species groups defined by the phenometric models (Weller et al., 2016). 
responsible for $70 \%$ of the whole-system water budget deficit, with deficit defined as the difference between outflow and inflow. We attributed the remaining 30\% to estimation errors (Sanchez et al., 2016). These values are considerably higher than transpiration contributions in wetlands located in cooler or more mesic places. Evapotranspiration accounted for $13 \%$ of a Dutch CTW water budget (Meuleman et al., 2003), 10\% for a CTW in Venice, Italy (Favero et al., 2007), and only 3\% in a CTW in Missouri, United States (Kadlec et al., 2010).

From another perspective, our estimates of summertime transpirational water losses equated to $30-35 \mathrm{~mm} \mathrm{~d}^{-1}$ while summer water losses via open water evaporation were estimated at roughly $10 \mathrm{~mm} \mathrm{~d}^{-1}$ (Sanchez et al., 2016). In some cases, these plant-mediated water losses are comparable to those reported for other wetlands. In a Mediterranean-climate CTW, Typha spp. transpired at a peak rate of $23 \mathrm{~mm} \mathrm{~d}^{-1}$ (Pedescoll et al., 2013) and Tuttulomondo et al. (2016) reported peak transpiration rates by the same genus of $35 \mathrm{~mm} \mathrm{~d}^{-1}$ for a demonstration CTW in Sicily, Italy. In contrast, Eichelmann et al. (2018) reported eddy fluxbased evapotranspiration losses from three restored wetlands in California's Sacramento-San Joaquin River delta of 996-1140 mm $\mathrm{yr}^{-1}$, or roughly $2.7 \mathrm{~mm} \mathrm{~d}^{-1}$ in this cooler Mediterranean climate. Additionally, the large transpirational water losses we have documented in the Tres Rios CTW are drawing oxygenated, $\mathrm{N}$-rich water into the soils, enhancing coupled nitrificationdenitrification (sensu Martin et al., 2003). Thus, our hot, dry climate is driving greater volumes of water and $\mathrm{N}$ into the vegetated marsh and its biogeochemically active soils, where most $\mathrm{N}$ uptake and processing is taking place.

It is the replacement of these large losses of water from the marsh, driven by the plants, that stimulated our hypothesis about a "Biological Tide." Quite simply, we hypothesized that there must be a gradual movement of surface water from the open water areas into the vegetated marsh to replace water being transpired by the plants. In Summer 2015, with the help of environmental engineering colleagues from the University of Strasbourg, we performed several controlled-flow tracer experiments using a fixed-wall flowthrough marsh flume. The surface velocities that we calculated from these tracer experiments ranged from 29 to $45 \mathrm{~cm} \mathrm{~h}^{-1}$ (Bois et al., 2017). Using plant biomass and transpiration data from July 2015, we estimated flow velocities of about $40 \mathrm{~cm} \mathrm{~h}^{-1}$ using our Sanchez et al. (2016) water budget approach. These Rhodamine tracer experiments confirmed that, in fact, the plants were controlling surface hydrology in this CTW-a phenomenon that, to our knowledge, has never before been documented in a wetland. Furthermore, the new water being brought into the marsh by the "Biological Tide" contained nutrients and other pollutants, and I present our analysis of how this phenomenon affected the $\mathrm{N}$ budget in the following section.

\section{Water Quality and Nutrient Budgets}

As I noted earlier, our water quality analysis and nutrient budget calculations focus on dissolved inorganic nitrogen (N). Treese et al. (2020) combined our water quality data with inflow and outflow data to calculate $\mathrm{N}$ fluxes and $\mathrm{N}$ uptake, or removal, rates for the entire 42 ha CTW system (Figure 4). We also calculated $\mathrm{N}$ fluxes for only the vegetated marsh system, and partitioned them into $\mathrm{N}$ uptake or removal associated with the Biological Tide vs. removal without it (Figure 5; Treese et al., 2020). The Biological Tide clearly enhanced the efficacy of the vegetated marsh to take up and process $\mathrm{N}$, particularly during the hot summer months. A summary of this enhancement, during the 6-month summer growing season and the entire year, demonstrates the value of the Biological Tide at the scales of the vegetated marsh and the entire 42 ha system (Table 2). Within the marsh proper, $\mathrm{N}$ removal from the water column was enhanced by more than $100 \%$ and during the growing season, when transpiration rates and plant biomass were both highest, the increase in $\mathrm{N}$ uptake was 126$184 \%$. At the scale of the entire CTW system, the Biological Tide increased $\mathrm{N}$ removal by $2.4-18 \%$ during the growing season and by an annual average of 2-35\% (Table 2). Martin et al. (2003) demonstrated that oxygenated water drawn into the soil by Typha sp. transpiration enhanced coupled nitrification-denitrification and overall $\mathrm{N}$ removal. This is almost certainly taking place in the Tres Rios soils. It is clear that this transpiration-driven phenomenon makes the Tres Rios CTW more effective at $\mathrm{N}$ uptake and removal.

\section{Open Water Aquatic Metabolism}

The vegetated marsh dominates $\mathrm{N}$ uptake and processing in the Tres Rios CTW. However, half of the 42 ha system is open water where primary productivity and heterotrophic respiration may be either a net source or a net sink for dissolved inorganic $\mathrm{N}$ in the water column. To address this, in 2017 we began sampling aquatic metabolism. We used the standard light-dark bottle technique, incubating water samples from the inflow and the outflow. We scaled the rates of net primary production and respiration to the entire system, and to the $2 \mathrm{~m}$ deep water column, and found that, on average, productivity accounted for 16.3 MT of $\mathrm{N}$ uptake annually $\left(=0.2 \mathrm{~g} \mathrm{~N} \mathrm{~m}^{-2} \mathrm{~d}^{-1}\right)$ while respiration below the photic zone and at night equated to 11.8 MT of $\mathrm{N}$ being remineralized annually $\left(=0.15 \mathrm{~g} \mathrm{~N} \mathrm{~m}^{-2} \mathrm{~d}^{-1}\right.$; Evans, 2020). The $\mathrm{N}$ uptake associated with this autotrophic water column is roughly $27 \%$ of the average annual $\mathrm{N}$ uptake by the vegetated marsh. However, our aquatic metabolism measurements do not account for $\mathrm{N}$ remineralization by aquatic animals larger than zooplankton or by birds, nor do they account for benthic processes in which the sediments underlying the open water areas may be a net source of $\mathrm{N}$, via aerobic decomposition processes, or a net sink of $\mathrm{N}$, via denitrification. Open water metabolism is our least well understood process in the Tres Rios CTW.

\section{Greenhouse Gas Fluxes}

Wetlands and their anaerobic soils may be significant sources of greenhouse gases to the atmosphere. Of most concern are $\mathrm{CH}_{4}$ and $\mathrm{N}_{2} \mathrm{O}$, and in 2012 and 2013 we quantified the fluxes of these gases across the air-water interface in the marsh and from Typha leaves (Ramos, 2017). The flux of both gases was consistently from the water to the air, with $\mathrm{CH}_{4}$ flux rates roughly an order of magnitude greater than $\mathrm{N}_{2} \mathrm{O}$ fluxes (Table 3). Scaling these area-specific rates to fluxes from the entire 21 ha marsh is not trivial. Based on our plant biomass measurements, roughly 


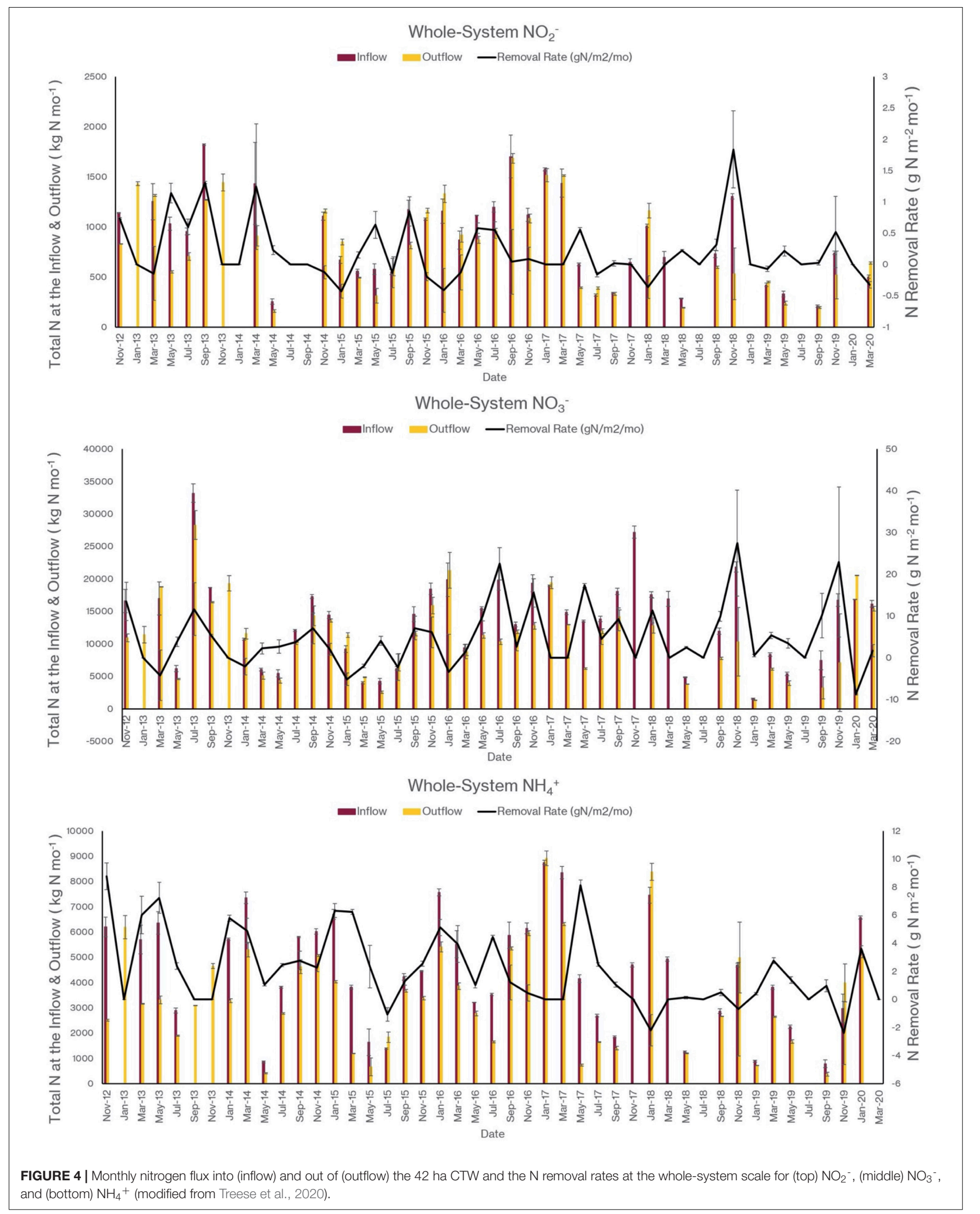




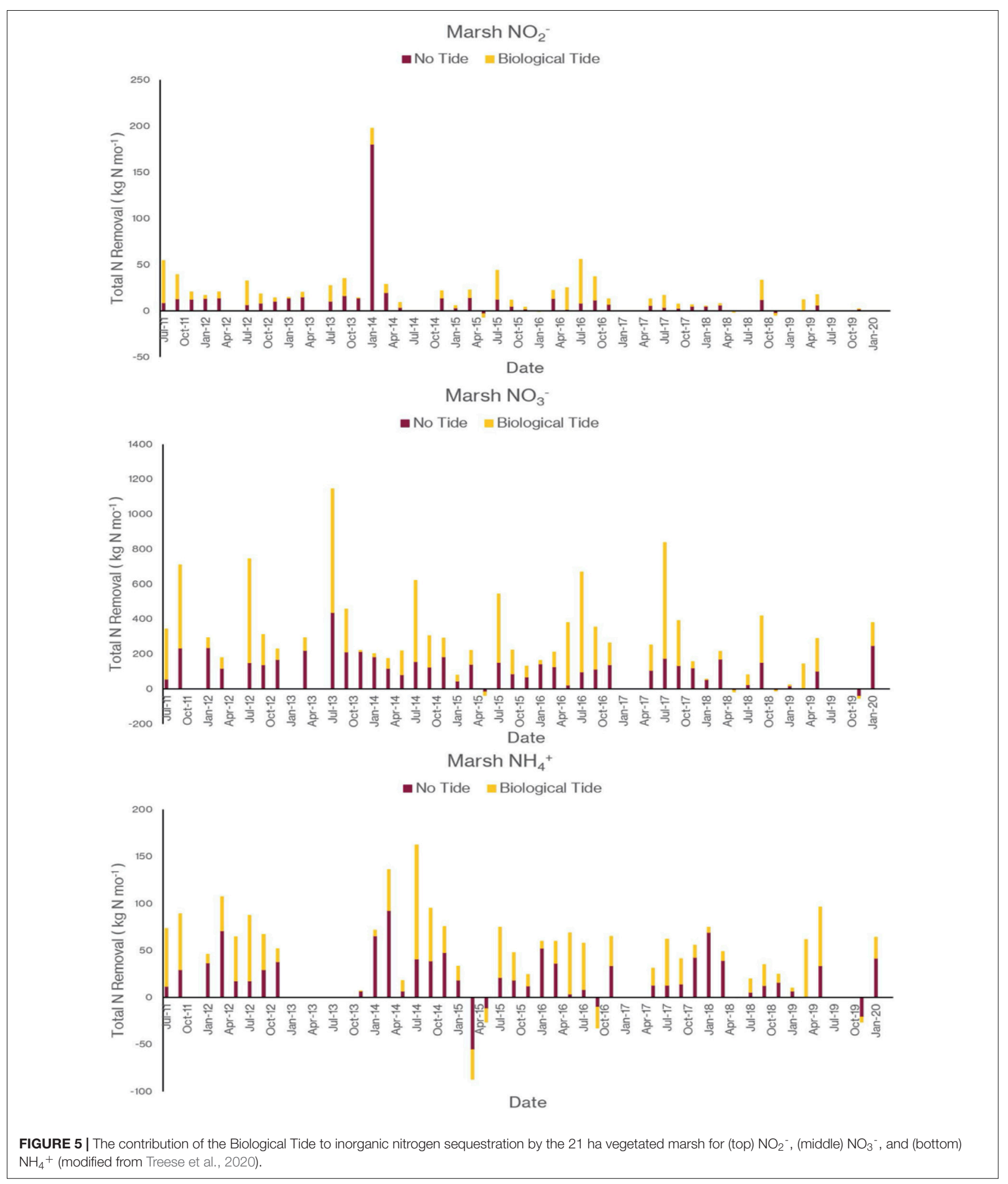

$5 \%$ of the water volume within the marsh is displaced by plant stems. In recent years we have observed a steady increase in the incidence of large "thatching" events, where substantial areas of plant biomass literally topple over and form large areas of dead biomass. Some of these unvegetated areas cover 10-100 s of $\mathrm{m}^{2}$. Our anecdotal evidence, again from the biomass sampling, 
TABLE 2 | Enhanced N removal due to the Biological Tide (\% improvement) for each dissolved inorganic nitrogen species at the whole system and marsh subsystem scales, where the Growing Season = March-September (modified from Treese et al., 2020).

\begin{tabular}{|c|c|c|c|}
\hline Analyte & Season & $\begin{array}{c}\text { Whole-system } \mathrm{N} \\
\text { removal enhancement } \\
42 \text { ha (\%) }\end{array}$ & $\begin{array}{c}\text { Marsh N removal } \\
\text { enhancement } \\
21 \text { ha (\%) }\end{array}$ \\
\hline \multirow[t]{2}{*}{$\mathrm{NO}_{2}^{-}$} & Year-round & 35.7 & 96.3 \\
\hline & Growing Season & 18.3 & 126 \\
\hline \multirow[t]{2}{*}{$\mathrm{NO}_{3}^{-}$} & Year-round & 9.54 & 145 \\
\hline & Growing Season & 12.1 & 184 \\
\hline \multirow[t]{2}{*}{$\mathrm{NH}_{4}+$} & Year-round & 2.04 & 110 \\
\hline & Growing Season & 2.37 & 133 \\
\hline
\end{tabular}

suggests that as much as $15 \%$ of the 21 ha of marsh is affected by this thatching at any given time. Because of the large volumes of dead biomass, these thatched areas have dramatically reduced air-water interaction. Thus, I conservatively estimated that the 21 ha marsh has an average of $168,000 \mathrm{~m}^{2}$ of surface area where the water and air interact. Using this number, I further estimated that the Tres Rios CTW marsh may produce $217-565 \mathrm{~g} \mathrm{CH}_{4} \mathrm{~h}^{-1}$ (1.03-2.7 $\mathrm{mg} \mathrm{CH}_{4} \mathrm{~m}^{-2} \mathrm{~h}^{-1}$ ) and 28-38 $\mathrm{g} \mathrm{N}_{2} \mathrm{O} \mathrm{h}^{-1}$ (133-181 $\mu \mathrm{g}$ $\left.\mathrm{N}_{2} \mathrm{O} \mathrm{m}^{-2} \mathrm{~h}^{-1}\right)$.

Greenhouse gas fluxes across the surface of Typha leaves showed considerably more variation than the air-water fluxes (Table 3) because these fluxes were not always from the leaves to the atmosphere. In fact, of the 49 plant-mediated $\mathrm{CH}_{4}$ fluxes that we observed, which ranged from -4.0 to $100.1 \mathrm{mg} \mathrm{CH}_{4}$ $\mathrm{kgdw}^{-1} \mathrm{~h}^{-1}$, the plants were a sink for $\mathrm{CH}_{4} 27 \%$ of the time. We were able to detect $\mathrm{N}_{2} \mathrm{O}$ exchange across the leaf surfaces

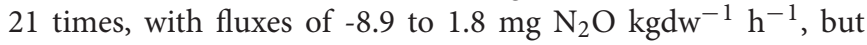
only nine times were the plants releasing $\mathrm{N}_{2} \mathrm{O}$ to the atmosphere (Ramos, 2017). These flux rates were considerably easier to scale because we have good estimates of Typha biomass (Figure 2). Using average biomass values, from 2011 to 2019, of 280, 130, and $21 \mathrm{MT}$ (1333, 619, and $100 \mathrm{~g} \mathrm{~m}^{-2}$ ) for summer, fall, and winter, respectively, I estimated that the vegetation at the Tres Rios CTW may release 16,500, 10,400, and $-10 \mathrm{~g} \mathrm{CH}_{4} \mathrm{~h}^{-1}(78,50$, and $-0.5 \mathrm{mg} \mathrm{CH}_{4} \mathrm{~m}^{-2} \mathrm{~h}^{-1}$ ) to the atmosphere while taking up 700,1800 , and $60 \mathrm{~g} \mathrm{~N}_{2} \mathrm{O} \mathrm{h}^{-1}\left(3.3,8.6\right.$, and $\left.0.3 \mathrm{mg} \mathrm{N}_{2} \mathrm{O} \mathrm{m}^{-2} \mathrm{~h}^{-1}\right)$ from the atmosphere during these respective seasons.

Balancing these whole-system estimates with the air-water exchange estimates suggests that the vegetation is by far the largest conduit of $\mathrm{CH}_{4}$ to the atmosphere at the same time the plants appear to be a net sink for $\mathrm{N}_{2} \mathrm{O}$. This is significant, of course, because $\mathrm{N}_{2} \mathrm{O}$ has a global warming potential of nearly
300 while the potential for $\mathrm{CH}_{4}$ is 25 (IPCC, 2007). I made an estimate combining the minimum values and the maximum values from the two types of fluxes, then scaled them to their $\mathrm{CO}_{2}$ equivalents. Methane released by the Tres Rios marshes totaled roughly $39 \mathrm{~kg} \mathrm{CO}_{2}$ equiv $\mathrm{h}^{-1}$ while $\mathrm{N}_{2} \mathrm{O}$ uptake totaled about $535 \mathrm{~kg} \mathrm{CO}_{2}$ equiv $\mathrm{h}^{-1}$. It appears that this CTW is actually a substantial sink for greenhouse gases, and this does not account for the fact that the wetland is highly productive and is also a sink for $\mathrm{CO}_{2}$. If confirmed, this has important implications for the Tres Rios CTW, and perhaps other CTW systems, as net sinks for both carbon and major greenhouse gases relative to carbon credit accounting (sensu Sapkota and White, 2020).

\section{DISCUSSION}

Constructed treatment wetlands have been an important component of critical UEI for decades, and their use continues to increase as cities search for more adaptive, flexible, and economical ways to manage wastewater and stormwater challenges (Greenway, 2005; Nivala et al., 2013; others). The scientific literature is rich with CTW information, including several books and reports written on engineering and design (e.g., Wallace and Knight, 2006; Kadlec and Wallace, 2009; Tao et al., 2017) and CTW typologies (Fonder and Headley, 2010, 2013). That said, much of the primary research that has been done and reported on CTW has focused on specific biogeochemical or ecological processes (e.g., Bachand and Horne, 1999; Palmer et al., 2009). There are far fewer whole-system analyses, sensu Kadlec et al. (2010), in the literature. Kadlec (2008) reported on four demonstration wetlands that were built at the same 91st Avenue wastewater treatment plant where our Tres Rios CTW is located. While he presented data that seem comparable to our findings, the systems he studied were very small ( $<1 \mathrm{ha})$ and his analysis focused on CTW efficacy at treating $\mathrm{N}$ in effluent after significant system interventions that included the total loss of vegetation in two cells and major hydrologic manipulations in the other two.

There are even fewer publications on whole-system analyses of CTW from arid or semi-arid climates. For example, Tao et al. (2017) recently reviewed $31 \mathrm{CTW}$ systems that were designed to treat wastewater for reuse. Three of these CTW are in Arizona, including our Tres Rios system. Several other CTW in their review analysis are in locations with high temperatures similar to those in Phoenix, but all are wetter climates. Two are in similarly dry climates, but not nearly as hot in the summer. Of the 31 systems in this Tao et al. (2017) review, only three had arid or semi-arid and hot conditions: One in the Negev Desert of Israel,

TABLE 3 | Average ( \pm SD) of greenhouse gas fluxes from the Tres Rios marshes (Ramos, 2017).

\begin{tabular}{|c|c|c|c|c|}
\hline Season & $\begin{array}{c}\mathrm{CH}_{4} \text { flux air-water } \\
\text { interface }\left(\mathrm{mg} \mathrm{m}^{-2} \mathrm{~h}^{-1}\right)\end{array}$ & $\begin{array}{c}\mathrm{CH}_{4} \text { flux Typha spp. } \\
\text { leaves (mg kgdw }{ }^{-1} \mathrm{~h}^{-1} \text { ) }\end{array}$ & $\begin{array}{c}\mathrm{N}_{2} \mathrm{O} \text { flux air-water } \\
\text { interface }\left(\mu \mathrm{g} \mathrm{m}^{-2} \mathrm{~h}^{-1}\right)\end{array}$ & $\begin{array}{l}\mathrm{N}_{2} \mathrm{O} \text { flux Typha spp. } \\
\text { leaves (mg kgdw }{ }^{-1} \mathrm{~h}^{-1} \text { ) }\end{array}$ \\
\hline Spring & $1.95 \pm 0.5$ & No data & $165.0 \pm 15$ & No data \\
\hline Summer & $3.36 \pm 0.6$ & $59.1 \pm 110.2$ & $225.0 \pm 20$ & $-2.4 \pm 8.4$ \\
\hline Fall & $2.32 \pm 0.6$ & $79.7 \pm 195.1$ & $200.0 \pm 20$ & $-13.7 \pm 30.9$ \\
\hline Winter & $1.29 \pm 0.4$ & $-0.5 \pm 4.9$ & $190.0 \pm 20$ & $-0.3 \pm 0.5$ \\
\hline
\end{tabular}


one in Ma'aden, Saudi Arabia, and Tres Rios. Because key data from these other two CTW were either not relevant or missing, I was unable to compare these systems with the Tres Rios CTW.

Primary production is a critical ecosystem process because it is the source of new organic energy that then fuels trophic dynamics and the rest of the ecosystem. We have quantified aboveground live biomass in the Tres Rios CTW marshes since July 2011 (Figure 2; Weller et al., 2016). Our summertime maximum aboveground biomass values are similar to those reported from other natural and constructed treatment wetlands (ranging from 790 to 2,200 gdw $\mathrm{m}^{-2}$; Van der Valk and Davis, 1978; Tanner, 2001; Kadlec and Wallace, 2009; Miller and Fujii, 2010). Over the last decade the plant community has been trending toward dominance by Typha sp. (Figure 2), which Weller et al. (2016) suggested may not be desirable. Regardless, we have observed no decline in ability of the vegetated marsh to sequester and process N. Lee et al. (2009) reviewed N removal by CTW systems and concluded that monospecific stands of vegetation achieved optimal $\mathrm{N}$ removal rates, but species diversity made the plant community more resilient to disturbances.

Total belowground biomass consistently averaged about 1,000 gdw $\mathrm{m}^{-2}$ (Weller et al., 2016; Crane, 2019). These values were comparable to estimates for S. tabernaemontani reported by Tanner $(1996,2001)$, somewhat lower than the 1,000 and $1,800 \mathrm{gdw} \mathrm{m}^{-2}$ reported for mixed stands of Typha spp. and S. acutus by Miller and Fujii (2010), but considerably lower than those reported for monospecific stands of $T$. latifolia (2900 gdw $\mathrm{m}^{-2}$; Kadlec and Wallace, 2009). We observed little interannual variation in aboveground:belowground biomass ratios, with values for all species groups combined ranging from $0.33 \pm 0.04$ to $1.71 \pm 0.42$ and with Typha spp. ratios consistently highest (Weller et al., 2016; Crane, 2019). Plant tissue N content showed no significant variation among species groups and no significant interannual variability-above ground $\% \mathrm{~N}$ ranged from $1.52 \pm 0.18$ to $1.64 \pm 0.11$ while belowground $\% \mathrm{~N}$ ranged from $0.77 \pm 0.12$ to $1.29 \pm 0.08$ (Weller et al., 2016; Crane, 2019). These ratios and our estimates of the amount of $\mathrm{N}$ stored in plant biomass (Table 2) are consistent with those reported by Pratt et al. (1980) and Kadlec and Wallace (2009) for Typha spp. and by Tanner (2001) for S. tabernaemontani.

As I noted above (Results, section "Greenhouse Gas Fluxes"), thatching has become a routine phenomenon in the Tres Rios marshes. We have observed that most new thatching happens between July and September, when aboveground biomass is maximal (Figure 2) and sizable stands of plants have literally grown too tall to support themselves. Our explanation for this phenomenon is that these plants are not limited by nutrient, water, or light availability and the system has minimal herbivory; they literally grow until their actual stature becomes limiting. Typha sp. stands are particularly vulnerable to this. It results in large areas of wetland that are covered with deep $(>0.5 \mathrm{~m})$ mats of senesced vegetation that often inhibit new vegetative growth for a year or more. It is difficult to find reference to this phenomenon in the literature, but it is similar to wrack mulching in salt marshes that leads to persistent patches of unvegetated wetland (Li and Pennings, 2016). Careful harvesting of some plant biomass in the summer could reduce thatching and its negative effects on productivity the following year. This would also remove a large amount of $\mathrm{N}$ bound in aboveground plant tissue, which could be composted and used in various urban applications. Routine removal of live plant biomass at peak productivity would also slow the long-term process of organic matter and $\mathrm{N}$ accumulation in CTW marshes (Kadlec and Wallace, 2009). In their work on two CTW systems, Kasak et al. (2020) reported that harvesting live plant biomass late in the growing season provided the best trade-off between high nutrient content in the plants and methane emissions from the cut stems. However, the harvesting process would have to be done carefully, to avoid major disturbance to the soil and its $\mathrm{N}$-processing microbial communities.

By far the most novel outcome of our near-decade of research at the Tres Rios CTW is our discovery of plant-mediated control of surface hydrology in the wetlands via transpirationa phenomenon we refer to as the Biological Tide (Sanchez et al., 2016; Bois et al., 2017). We use this term and concept with the caveat that its analog-astronomical tides in coastal wetlandsare bi-directional while the Biological Tide is analogous only to a flooding astronomical tide. Transpiration-mediated control of shallow subsurface water flow has been documented in a number of wetlands, including in tree islands of the Florida Everglades (Bazante et al., 2006; Troxler-Gann and Childers, 2006; Sullivan et al., 2012) and the Okavango Delta, Botswana (Bauer-Gottwein et al., 2007; Ramberg and Wolski, 2008) and experimentally in Typha sp. wetlands (Martin et al., 2003). Our discovery is the first time that biotic control of surface hydrology has been demonstrated in any wetland, to our knowledge. Furthermore, we used our water quality data and ensuing $\mathrm{N}$ budgets to demonstrate that this Biological Tide is demonstrably increasing the nutrient uptake and processing efficacy of the Tres Rios CTW marshes, especially during the hot, dry growing season (Treese et al., 2020). In our periodic research charrettes with managers, engineers, and administrators in the City of Phoenix Water Services Department it is this finding that intrigues and excites them the most.

Another similarly intriguing outcome of our Tres Rios research is that these CTW marshes appear to be a sink, not a source, of greenhouse gases (Ramos, 2017). This was not expected, as CTW and wetlands in general have generally been shown to be sources of various greenhouse gases (Bridgham et al., 2006; IPCC, 2013), at least within the first several decades to centuries of their existence (Neubauer, 2014). The system is a net source of $\mathrm{CH}_{4}$ and $\mathrm{N}_{2} \mathrm{O}$ across the air-water interface, and the leaves of the dominant macrophyte species group, Typha sp., are also a source of $\mathrm{CH}_{4}$. However, those leaves appear to be a sink for $\mathrm{N}_{2} \mathrm{O}$ (Table 3 ). In a recent publication on greenhouse gas fluxes in a restored wetland in California's Sacramento Delta, Windham-Myers et al. (2018) reported that marshes vegetated by the same species as Tres Rios were consistent sinks for $\mathrm{N}_{2} \mathrm{O}$ : Daytime fluxes averaged $-0.24 \pm 0.04 \mathrm{mg} \mathrm{m}^{-2} \mathrm{~h}^{-1}$ and nighttime fluxes averaged $0.06 \pm 0.26 \mathrm{mg} \mathrm{m}^{-2} \mathrm{~h}^{-1}$. Their $\mathrm{N}_{2} \mathrm{O}$ uptake rates are lower than my estimates of 3.3, 8.6, and $0.3 \mathrm{mg} \mathrm{N}_{2} \mathrm{O}$ $\mathrm{m}^{-2} \mathrm{~h}^{-1}$, based on Ramos (2017), but the direction of the fluxnet uptake-is the same. And when I accounted for the global warming potential of both $\mathrm{CH}_{4}$ and $\mathrm{N}_{2} \mathrm{O}$, in $\mathrm{CO}_{2}$ equivalents, 


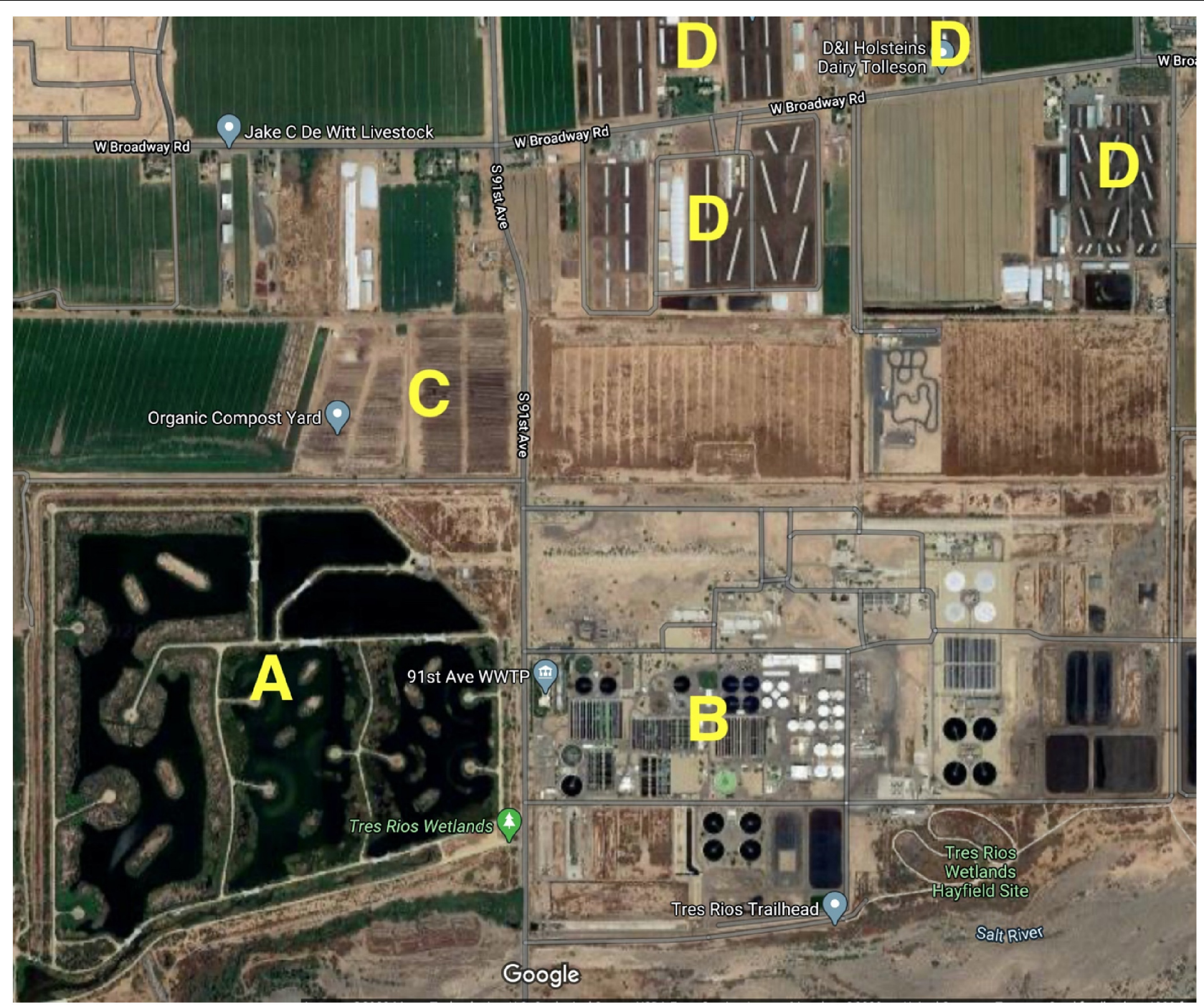

FIGURE 6 | Aerial view of the vicinity around the Tres Rios CTW. (A) The Tres Rios CTW; (B) the City of Phoenix 91st Avenue wastewater treatment plant; (C) the large manure composting facility immediately north of the CTW (the tightly stacked horizontal lines in the image are piles of composting manure that are 2-3 $\mathrm{m}$ tall); (D) several concentrated animal feeding operations (CAFOs) nearby which are the source of the manure being composted (image from Google maps).

the impact of the Tres Rios CTW being a potential sink for global warming potential was substantial.

But this finding begs the question: What is the source of the $\mathrm{N}_{2} \mathrm{O}$ that the Tres Rios marshes appear to be sequestering? To answer this question we must look at the CTW from a slightly higher altitude (Figure 6). The largest slaughterhouse in the U.S. southwest is about $5 \mathrm{~km}$ north, on 91st Avenue. Associated with it, at least four large concentrated animal feeding operations (CAFO) are located within $0.5 \mathrm{~km}$ of Tres Rios, to the northeast (Figure 6), with more located further north but out of the image. The large volumes of manure being produced by these CAFOs are being composted in an open air facility that borders the Tres Rios CTW to the north (Figure 6). Cow manure is a welldocumented source of $\mathrm{N}_{2} \mathrm{O}$, as is the process of composting that manure (Sommer et al., 2004; others). Given the proximity to this large composting operation, and the huge volumes of manure it continuously processes, I am hypothesizing that the surface atmosphere over the CTW may contain unusually large concentrations of $\mathrm{N}_{2} \mathrm{O}$. If this is the case, then not only are the Tres Rios CTW marshes a net sink for global warming potential but they are also mitigating [at least some of] the release of $\mathrm{N}_{2} \mathrm{O}$ from this large regional meat operation before it can get into the upper atmosphere. This interesting hypothesis clearly needs further investigation.

\section{CONCLUSION}

As cities face increasing uncertainties and sustainability challenges moving into the future, the use of UEI will almost certainly increase. Constructed treatment wetlands are an important form of UEI, and their use will likely also increase. 
Aridland cities face additional uncertainties and challenges because of increasing limitations on water supplies and increasing reliance on water reclamation strategies. Our findings from the Tres Rios CTW in Phoenix are particularly relevant and important because little systems-level research of this kind has been done in arid or semi-arid climates-which is curious because nearly $30 \%$ of the earth's land surface is found in these climatic settings. Our work focuses attention on an important trade-off that must be considered when applying CTW to wastewater treatment challenges in dry cities: Transpirational water losses to the atmosphere in hot, dry climates make these CTW more effective at treating nutrients and pollutants than their counterparts in cooler or more mesic settings, but transpired water cannot be reused. Any cost-benefit analysis of wastewater treatment technologies for use in hot, dry cities should account for this trade-off. I know from our colleagues in the Phoenix Water Services Department is that it would have cost roughly $\$ 5$ Billion to technologically accomplish the $\mathrm{N}$ reduction that the Tres Rios CTW is now providing, at a construction cost of only about $\$ 100$ Million. The relatively small fraction of total effluent inflows that are being lost via transpiration and evaporation would seem a small "water price" to pay for this critical ecosystem service.

At a larger scale, it is worth summarizing the water budget for the Phoenix Metro Area. By the late 1930s, a series of seven dams and reservoirs on the Salt and Verde Rivers to the north and east had been constructed. This system directs $100 \%$ of the flow of these two rivers and their large watersheds into Phoenix, via canals and pumps, for human uses. Thus, the Salt River, which used to flow through the Valley of the Sun, has not been a perennial river for more than 80 years. Most of this urban water goes to outdoor uses, such as irrigation and swimming pools. Municipal wastewater effluent is recycled within the city for non-agricultural irrigation (e.g., golf courses, parks) or is returned to the local aquifer for future use. Today, the Salt River downstream of the Tres Rios CTW is the only river reach in the valley with surface flow. And all of that water is reclaimed for agricultural irrigation less than $10 \mathrm{~km}$ downstream, at the Lower Buckeye Diversion Dam. As Metson et al. (2012) noted, the only way water actually leaves the Valley of the Sun is to the atmosphere.

We are currently applying what we have learned from the Tres Rios CTW to design recommendations for future CTW built in hot, dry cities. We are focused on optimizing for the Biological Tide phenomenon via several strategies. The types of vegetation used in these CTWs should include native wetland plant species that have the highest biomass-specific transpiration rates. The spatial configuration of vegetated marsh and open water in these CTW should optimize the opportunity for water to come into contact with vegetated marshes, as they are far more effective at $\mathrm{N}$ removal that the open water bodies. We are currently working with our colleagues at the University of Strasbourg to develop a spatially articulate hydrodynamic model that also simulates basic biogeochemical processes, plant productivity, and transpirational water losses. Once this model has been validated with our data, we will use it to investigate various design alternatives with the goal of determining spatial configurations of marsh and open water that optimize $\mathrm{N}$ removal in aridland CTW systems. Our goal is to enhance the efficacy of future aridland CTW to further promote use of this efficient UEI, moving cities toward more resilient and sustainable futures as they face complex challenges with growing populations and limited water resources.

A final note. For nearly a decade our Tres Rios CTW work has provided dozens of young volunteers with an opportunity to experience ecological field and lab research. For some it has been helping out on a few field trips, for others it has included their own research projects. This is an excellent example of how blurring the lines between research and education can enhance the "STEM pipeline" and increase diversity in the next generation of scientists and students by giving an awareness of, and interest in, science (sensu Beltran et al., 2020). Quantifying the impacts of this influence is difficult, but it is easy to see the difference that experiencing ecological research makes for young people when you look into their faces as they are doing field work. Few rewards are better than this.

\section{DATA AVAILABILITY STATEMENT}

The datasets presented in this study can be found in online repositories. The names of the repository/repositories and accession number(s) can be found below: https://sustainability. asu.edu/caplter/research/long-term-monitoring/tres-rioswetland-dynamics/ (Childers et al., 2018).

\section{AUTHOR CONTRIBUTIONS}

The author confirms being the sole contributor of this work and has approved it for publication.

\section{FUNDING}

Our Tres Rios research was supported by the National Science Foundation through its support of the Central Arizona-Phoenix Long-Term Ecological Research Program (Grant Nos. DEB1027188, DEB-1637590, and DEB-1832016).

\section{ACKNOWLEDGMENTS}

The research I have synthesized here has been largely conducted by dozens of student volunteers over the years. There is not space here to acknowledge all of their help, but I will call out those people who have spent considerable time in the field and the lab. Paid staff have included Laura Turnbull, Dax Mackay, Chris Sanchez, and Dakota Tallman. Graduate students have included Amanda Suchy, Eric Chapman, Ben MacNeille, Jorge Ramos (Tres Rios dissertation), Chris Sanchez, Jared Stoltzfus, Ben Warner, and Nich Weller. Austin Crane, Rett Evans, Sawyer Treese, and Nich Weller conducted their honors thesis research at Tres Rios for ASU's Barrett the Honors College. Jadyn Hicks, Grace Whitler, Nadine Hubbard, and Brad Niska used 
their Tres Rios research projects to fulfill their Sustainability Undergraduate Research Experience obligations in ASU's School of Sustainability. Other students who had research projects or have spent a great deal of time working at Tres Rios include Sierra Kubicki, Olga Epshtein, Chris Coleman, Derek Duran, and Dakota Tallman. Special thanks to Paul Bois and colleagues at the University of Strasbourg for our enduring collaborations. These

\section{REFERENCES}

Ahern, J. (2011). From fail-safe to safe-to-fail: sustainability and resilience in the new urban world. Landsc. Urban Plan. 100, 341-343. doi: 10.1016/j. landurbplan.2011.02.02

Ahern, J. (2013). Urban landscape sustainability and resilience: the promise and challenges of integrating ecology with urban planning and design. Landsc. Ecol. 28, 1203-1212. doi: 10.1007/s10980-012-9799-z

Bachand, P. A., and Horne, A. J. (1999). Denitrification in constructed free-water surface wetlands: II. Effects of vegetation and temperature. Ecol. Eng. 14, 17-32. doi: 10.1016/S0925-8574(99)00017-8

Bauer-Gottwein, P., Langer, T., Prommer, H., Wolski, P., and Kinzelbach, W. (2007). Okavango Delta islands: interaction between density-driven flow and geochemical reactions under evapoconcentration. J. Hydrol. 335, 389-405. doi: 10.1016/j.jhydrol.2006.12.010

Bazante, J., Jacobi, G., Solo-Gabriele, H., Reed, D., Mitchell-Bruker, S., Childers, D. L., et al. (2006). Hydrologic measurements and implications for tree island formation within Everglades National Park. J. Hydrol. 329, 606-619. doi: 10. 1016/j.jhydrol.2006.03.011

Beltran, R. S., Marnocha, E., Race, A., Croll, D. A., Dayton, G. H., and Zavaleta, E. (2020). Field courses narrow demographic achievement gaps in ecology and evolutionary biology. Ecol. Evol. 10, 5184-5196. doi: 10.1002/ece3.6300

Bois, P., Childers, D. L., Corlouer, T., Laurent, J., Massicot, A., Sanchez, C. A., et al. (2017). Confirming a plant-mediated "Biological Tide" in an aridland constructed treatment wetland. Ecosphere 8, 1-16. doi: 10.1002/ecs2.1756

Bridgham, S. D., Megonigal, J. P., Keller, J. K., Bliss, N. B., and Trettin, C. (2006). The carbon balance of North American wetlands. Wetlands 26, 889-916. doi: 10.1672/0277-5212(2006)26[889:tcbona]2.0.co;2

Chester, M. H., and Allenby, B. R. (2019). Infrastructure as a wicked complex process. Elementa7:21. doi: 10.1525/elementa.360

Childers, D. L., Bois, P., Hartnett, H. E., McPhearson, T., Metson, G. S., and Sanchez, C. A. (2019). Urban ecological infrastructure: an inclusive concept for the non-built urban environment. Elementa 7:46. doi: 10.1525/elementa. 385

Childers, D. L., Cadenasso, M. L., Grove, J. M., Marshall, V., McGrath, B., and Pickett, S. T. A. (2015). An ecology for cities: a transformational nexus of design and ecology to advance climate change resilience and urban sustainability. Sustainability 7, 3774-3791. doi: 10.3390/su7043774

Childers, D. L., Pickett, S. T. A., Grove, J. M., Ogden, L., and Whitmer, A. (2014). Advancing urban sustainability theory and action: challenges and opportunities. Landsc. Urban Plan. 125, 320-328. doi: 10.1016/j.landurbplan. 2014.01.022

Childers, D., Sanchez, C., and Weller, N. (2018). Long-term monitoring and research of the ecology of the Tres Rios constructed treatment wetland, Phoenix, AZ, ongoing since 2011 ver 2. Environ. Data Initiat. doi: 10.6073/ pasta/3eb1f02c8db033f63a144a6f9d778fa7

Crane, A. (2019). Plant Contributions to the Nitrogen Budget of a Constructed Treatment Wetland in PHOENIX, AZ. Honors Thesis, Arizona State University, Tempe, AZ.

Eichelmann, E., Hemesa, K. S., Knox, S. H., Oikawa, P. Y., Chamberlain, S. D., Sturtevant, C., et al. (2018). The effect of land cover type and structure on evapotranspiration from agricultural and wetland sites in the SacramentoSan Joaquin River Delta. California. Agric. For. Meteorol. 256-257, 179-195. doi: 10.1016/j.agrformet.2018.03.007

Evans, J. B. (2020). Aquatic Primary Productivity and Ecosystem Metabolism: Tres Rios Constructed Treatment Wetlands. Honors Thesis, Arizona State University, Tempe, AZ. are just a few of many, and my apologies if there are other Tres Rios devotees whom I have forgotten here. Thanks to the City of Phoenix Water Services Department staff and administrators for allowing us access to the Tres Rios CTW site since July 2011. And special thanks to Bob Upham, the CoP's chief engineer on the project for the first few years of our research, for his dedicated support of our work.

Favero, L., Mattiuzzo, E., and Franco, D. (2007). Practical results of a water budget estimation for a constructed wetland. Wetlands 27, 230-239. doi: 10.1672/ 0277-5212(2007)27[230:proawb]2.0.co;2

Fonder, N., and Headley, T. (2010). "Systematic classification, nomenclature, and reporting for constructed treatment wetlands," in Water and Nutrient Management in Natural and Constructed Wetlands, ed. J. Vymazal (Dordrecht: Springer), 191-219. doi: 10.1007/978-90-481-9585-5_15

Fonder, N., and Headley, T. (2013). The taxonomy of treatment wetlands: a proposed classification and nomenclature system. Ecol. Eng. 51, 203-211. doi: 10.1016/j.ecoleng.2012.12.011

Gilrein, E. J., Carvalhaes, T. M., Markolf, S. A., Chester, M. H., Allenby, B. R., and Garcia, M. (2019). Concepts and practices for transforming infrastructure from rigid to adaptable. Sustain. Resilient Infrastruct. 1-22. doi: 10.1080/23789689. 2019.1599608

Green, M., Shaul, N., Belaivski, M., Sabbah, I., Ghattas, B., and Tarre, S. (2006). Minimizing land requirement and evaporation in small wastewater treatment systems. Ecol. Eng. 26, 266-271. doi: 10.1016/j.ecoleng.2005.10.007

Greenway, M. (2005). The role of constructed wetlands in secondary effluent treatment and water reuse in subtropical and arid Australia. Ecol. Eng. 25, 501-509. doi: 10.1016/j.ecoleng.2005.07.008

Grimm, N. B., Faeth, S. H., Golubiewski, N. E., Redman, C. L., Wu, J., Bai, X., et al. (2008). Global change and the ecology of cities. Science 319, 756-760. doi: $10.1126 /$ science. 1150195

Grimm, N. B., and Fisher, S. G. (1986). Nitrogen limitation potential of Arizona streams and rivers. Arizona Nevada Acad. Sci. 21,31-44.

Grove, J. M. (2009). "Cities: managing densely settled social-ecological systems," in Principles of Ecosystem Stewardship: Resilience-Based Natural Resource Management in a Changing World, eds C. Folke, G. P. Kofinas, and F. S. Chapin III (New York, NY: Springer), 281-294. doi: 10.1007/978-0-387-730 33-2_13

Helmrich, A., and Chester, M. H. (2020). Reconciling complexity and deep uncertainty in infrastructure design for climate adaptation. Sustain. Resilient Infrastruct. doi: 10.1080/23789689.2019.1708179

IPCC (2013). "Climate Change 2013: the physical science basis," in Contribution of Working Group I to the Fifth Assessment Report of the Intergovernmental Panel on Climate Change, eds T. F. Stocker, D. Qin, G.-K. Plattner, M. Tignor, S. K. Allen, J. Boschung, et al. (Cambridge: Cambridge University Press), 1535.

IPCC (2007). IPCC Fourth Assessment Report: Climate Change 2007. Cambridge: Cambridge University Press.

Kadlec, R. H. (2008). The effects of wetland vegetation and morphology on nitrogen processing. Ecol. Eng. 33, 126-141. doi: 10.1016/j.ecoleng.2008.02.012

Kadlec, R. H., Cuvellier, C., and Stober, T. (2010). Performance of the Columbia, Missouri, treatment wetland. Ecol. Eng. 36, 672-684. doi: 10.1016/j.ecoleng. 2009.12.009

Kadlec, R. H., and Wallace, S. (2009). Treatment Wetlands, 2nd Edn. New York, NY: CRC Press.

Kasak, K., Valach, A. C., Rey-Sanchez, C., Kill, K., Shortt, R., Liu, J., et al. (2020). Experimental harvesting of wetland plants to evaluate trade-offs between reducing methane emissions and removing nutrients accumulated to the biomass of constructed wetlands. Sci. Total Environ. 715:136960. doi: 10.1016/ j.scitotenv.2020.136960

Lee, C., Fletcher, T., and Sun, G. (2009). Nitrogen removal in constructed wetland systems. Eng. Life Sci. 9, 11-22. doi: 10.1002/elsc.200800049

Li, S., and Pennings, S. C. (2016). Disturbance in georgia saltmarshes: variation across space and time. Ecosphere 7:e01487. doi: 10.1002/ecs2.1487

Martin, J., Hofherr, E., and Quigley, M. F. (2003). Effects of Typha latifolia transpiration and harvesting on nitrate concentrations in surface water of 
wetland microcosms. Wetlands 23, 835-844. doi: 10.1672/0277-5212(2003) 023[0835:eotlta]2.0.co;2

Melosi, M. V. (2000). The Sanitary City: Environmental Services in Urban America From Colonial Times to the Present. Baltimore, MA: Johns Hopkins University Press.

Metson, G., Hale, R., Iwaniec, D., Cook, E., Corman, J., Galletti, C., et al. (2012). Phosphorus in Phoenix: a budget and spatial representation of phosphorus in an urban ecosystem. Ecol. Appl. 22, 705-721. doi: 10.1890/11-0865.1

Meuleman, A. F. M., van Logtestigin, R., Rijs, G. B. J., and Verhoeven, J. T. A. (2003). Water and mass budgets of a vertical-flow constructed wetland used for wastewater treatment. Ecol. Eng. 20, 31-44. doi: 10.1016/S0925-8574(03) 00002-8

Miller, R. L., and Fujii, R. (2010). Plant community, primary production, and environmental conditions following wetland re-establishment in the Sacramento-San Joaquin Delta, California. Wetlands Ecol. Manag. 18, 1-16. doi: 10.1007/s11273-009-9143-9

Neubauer, S. C. (2014). On the challenges of modeling the net radiative forcing of wetlands: reconsidering Mitsch et al. 2013. Landsc. Ecol. 29, 571-577. doi: 10.1007/s10980-014-9986-1

Nivala, J., Headley, T., Wallace, S., Bernhard, K., Brix, H., van Afferden, M., et al. (2013). Comparative analysis of constructed wetlands: the design and construction of the ecotechnology research facility in Langenreichenbach, Germany. Ecol. Eng. 61, 527-543. doi: 10.1016/j.ecoleng.2013.01.035

Palmer, H., Beutel, M., and Gebremariam, S. (2009). High rates of ammonia removal in experimental oxygen-activated nitrification wetland mesocosms. J. Environ. Eng. 135, 972-979. doi: 10.1061/(ASCE)EE.1943-7870.0000053

Pedescoll, A., Sidrach-Cardona, R., Sánchez, J. C., and Bécares, E. (2013). Evapotranspiration affecting redox conditions in horizontal constructed wetlands under Mediterranean climate: influence of plant species. Ecol. Eng. 58, 335-343. doi: 10.1016/j.ecoleng.2013.07.007

Pratt, D. C., Bonnewell, V., Andrews, N. J., and Kim, J. H. (1980). Potential of Cattails as an Energy Source. Final report (No. NP-25052). St. Paul, MN.: University of Minnesota.

Ramberg, L., and Wolski, P. (2008). Growing islands and sinking solutes: processes maintaining the endorheic Okavango Delta as a freshwater system. Plant Ecol. 196, 215-231. doi: 10.1007/s11258-007-9346-1

Ramos, J. (2017). Methane and Nitrous Oxide Fluxes From Water, Plants, and Soils of a Constructed Treatment Wetland in Phoenix, AZ. Ph.D. Dissertation, Arizona State University, Tempe, AZ.

Sanchez, C. A., Childers, D. L., Turnbull, L., Upham, R., and Weller, N. A. (2016). Aridland constructed treatment wetlands II: plant mediation of surface hydrology enhances nitrogen removal. Ecol. Eng. 97, 658-665. doi: 10.1016/j. ecoleng.2016.01.002

Sapkota, Y., and White, J. R. (2020). Carbon offset market methodologies applicable for coastal wetland restoration and conservation in the United States: a review. Sci. Total Environ. 701:134497. doi: 10.1016/j.scitotenv.2019.134497

Sommer, S. G., McGinn, S. M., Hao, X., and Larney, F. J. (2004). Techniques for measuring gas emissions from a composting stockpile of cattle manure. Atmos. Environ. 38, 4643-4652. doi: 10.1016/j.atmosenv.2004.05.014

Sullivan, P., Price, R. M., Miralles-Wilhelm, F., Ross, M. S., Scinto, L. J., Dreschel, T. W., et al. (2012). The role of recharge and evapotranspiration as hydraulic drivers of ion concentrations in shallow groundwater on Everglades tree islands, Florida (USA). Hydrol. Process. 28, 293-304. doi: 10.1002/hyp.9575
Tanner, C. C. (1996). Plants for constructed wetland treatment systems-a comparison of the growth and nutrient uptake of eight emergent species. Ecol. Eng. 7, 59-83. doi: 10.1016/0925-8574(95)00066-6

Tanner, C. C. (2001). Growth and nutrient dynamics of soft-stem bulrush in constructed wetlands treating nutrient-rich wastewaters. Wetlands Ecol. Manag. 9, 49-73. doi: 10.1023/A:1008454901954

Tanner, C. C., Sukias, J. P. S., Headley, T. R., Yates, C. R., and Stott, R. (2012). Constructed wetlands and denitrifying bioreactors on-site and decentralized water treatment: comparison of five alternative configurations. Ecol. Eng. 42, 112-123. doi: 10.1016/j.ecoleng.2012.01.022

Tao, W., Sauba, K., Fattah, K. P., and Smith, J. R. (2017). Designing constructed wetlands for reclamation of pretreated wastewater and stormwater. Rev. Environ. Sci. Technol. 16, 37-57. doi: 10.1007/s11157-016-9419-5

Treese, S., Childers, D. L., and Sanchez, C. A. (2020). Long-term trends in nitrogen removal by an aridland constructed treatment wetland. Wetlands.

Troxler-Gann, T., and Childers, D. L. (2006). Relationships between hydrology and soils describe vegetation patterns in three seasonally flooded tree islands of the southern Everglades. Florida. Plant and Soil. 279, 271-286. doi: 10.1007/ s11104-005-2362-9

Tuttulomondo, T., Leto, C., La Bella, S., Leone, R., Virga, G., and Licata, M. (2016). Water balance and pollutant removal efficiency when considering evapotranspiration in a pilot-scale horizontal subsurface flow constructed wetland in Western Sicily (Italy). Ecol. Eng. 87, 295-304. doi: 10.1016/j.ecoleng. 2015.11.036

Van der Valk, A. G., and Davis, C. B. (1978). "Primary production of prairie glacial marshes," in Freshwater Wetlands: Ecological Processes and Management Potential, eds R. E. Good, D. F. Whigham, and R. L. Simpson (New York, NY: Academic Press), 21-37.

Wallace, S. D., and Knight, R. L. (2006). Small-Scale Constructed Wetland Treatment Systems: Feasibility, Design Criteria, and O\&M Requirements. Alexandria, VA: Water Environment Research Foundation (WERF)

Weller, N. A., Childers, D. L., Turnbull, L., and Upham, R. F. (2016). Aridland constructed treatment wetlands I: macrophyte productivity, community composition, and nitrogen uptake. Ecol. Eng. 97, 649-657. doi: 10.1016/j. ecoleng.2015.05.044

Wigginton, N. S., Fahrenkamp-Uppenbrink, J., Wible, B., and Malakoff, D. (2016). Cities are the future. Science 352, 904-905.

Windham-Myers, L., Bergamaschi, B., Anderson, F., Knox, S., Miller, R., and Fujii, R. (2018). Potential for negative emissions of greenhouse gases (CO2, CH4 and $\mathrm{N} 2 \mathrm{O}$ ) through coastal peatland re-establishment: novel insights from high frequency flux data at meter and kilometer scales. Environ. Res. Lett. 13:045005. doi: 10.1088/1748-9326/aaae74

Conflict of Interest: The author declares that the research was conducted in the absence of any commercial or financial relationships that could be construed as a potential conflict of interest.

Copyright (c) 2020 Childers. This is an open-access article distributed under the terms of the Creative Commons Attribution License (CC BY). The use, distribution or reproduction in other forums is permitted, provided the original author(s) and the copyright owner(s) are credited and that the original publication in this journal is cited, in accordance with accepted academic practice. No use, distribution or reproduction is permitted which does not comply with these terms. 